\title{
Performance evaluation of project management implementation based on PMBOK- 2008 standard (case study: Ahvaz Metro project)
}

\author{
Khashayar Bagherinia*, Masoud Olapour \\ Department of Civil Engineering, Khouzestan Science and Research Branch, Islamic Azad University, Ahvaz, Iran
}

\section{A R T I C L E I N F O}

\section{Article history:}

Received 15 April 2016

Received in revised form

7 August 2016

Accepted 16 September 2016

\section{Keywords:}

Performance evaluation

PMBOK

Processes and areas of project

Management knowledge

Compliance and non-compliance

\begin{abstract}
A B S T R A C T
The aim of this research is to evaluate performance of project management based on PMBOK standards. Since the performance evaluation process, evaluation of potential components specified using weighted criteria related key performance measures to compare the future is to make decisions and should always during the project life cycle and project-based organizations to be studied in this research was carried about on a project-driven organization. In this regard, evaluation and audit of the project management team of each process and the establishment of Project Management Knowledge areas Should be based on the guidelines of knowledge management implementation project. The deviation from the standard of each process and eventually in all areas of project management is obtained. Authentication capabilities and abilities, and weaknesses in project management are identified in the Ahavaz Metro Project. The amount of deviation in any field and strengths and weaknesses are realized for the project management team to improve management and continuous improvement in project life cycle solutions are offered.
\end{abstract}

(C) 2016 The Authors. Published by IASE. This is an open access article under the CC BY-NC-ND license (http://creativecommons.org/licenses/by-nc-nd/4.0/).

\section{Introduction}

Ahwaz LRT Line 1 includes 2 tunnels in $24 \mathrm{~km}$ and 23 underground stations from northeast to southwest passing downtown which are connected by two tunnels (internal diameter: $5.90 \mathrm{~m}$ and boring diameter: $6.8 \mathrm{~m}$ ). The project is under construction.

One of the problems of developing countries in successful implementation of national economic plans and projects that leads to the loss of many human and financial resources is the non-application of project management techniques and nonintegrated scientific organization of the projects by senior managers and companies active in these countries. Previous experiences of organizations in implementation of projects indicate suffering irreparable damages due to carelessness towards the power of organization and management of projects. This negligence will lead to non-efficiency of projects during operation which is mainly due to two factors: a steep rise of costs during the execution period and its time delays. Sometimes, less accuracy in

* Corresponding Author.

Email Address: khashayarb@kayson-ir.com (K. Bagherinia) https://doi.org/10.21833/ijaas.2016.09.003

2313-626X/C) 2016 The Authors. Published by IASE.

This is an open access article under the CC BY-NC-ND license

(http://creativecommons.org/licenses/by-nc-nd/4.0/) estimating the time and cost of project implementation could be the reason for it. But most of the time, weak project management is the major factor in this regard. For these reasons, today, some standards are developed for project management in the world in order to ensure executive methods of these standards by identifying the elements related to the provided standards which address other project management issues such as logistics, scope, integration and risks in addition to cost and time. PMBOK is a standard dealing with the requirements and obligations using guidelines and tools. In other words, it is a set of guidelines that specifies the methods, principles, techniques, and the tools necessary to manage projects of any size and type, regardless of a particular industry. But it does not provide an implementation methodology. However, these requirements are provided for managing a project, while an organization must design and implement an appropriate system in accordance with the PMBOK standard to manage a set of projects. Accordingly, in order to achieve the standard deviation and compliance, audit is carried out so as to identify the non-compliance of the administrative processes of the project-based organization and obtain and improve a system to implement the standard. Responsibility and management of the specified processes in standard is the duty of the project manager. Hence, the 
performance of project manager will have significant impacts on the functions and achievements of the project or organization.

\section{Research questions}

The standard deviation of the Project Management Body of Knowledge PMBOK What is project management?

Questions secondary research: Is the project management performance evaluation necessary?

The Project Management Body of Knowledge What is the standard deviation?

There is a mismatch in executive and managerial processes is to what extent and how much is acceptable?

To what extent is the project objectives achieved? What is the optimal project management performance?

\section{An introduction to PMBOK standards}

In 1961, the Project Management Institute was founded by five volunteers. Developing project management standards, exchanging knowledge and experiences of project managers, and conducting research to improve project management methods were of the main goals of this institute. After that, American National Standards Institute confirmed the project management institute for development of project management standards. One of these standards is the PMBOK (Kamandi and Darabi, 2009) guide. Its development started in 1987 with the aim of standardizing information and experiences of project managers accepted by most managers. PMBOK guide has divided project management into nine (9) knowledge areas, five (5) process groups, and forty-two (42) processes - Fourth Edition (2008)( Zoka'ei, 2008). PMPOK processes overlap and transact with each other. PMBOK is as comprehensive as it can be used as a as a guide for management in most projects. As well, flexibility of this standard provides compatibility with specific projects such as construction or state projects.

The approach used to develop PMBOK is compatible with the "Capability Maturity Model Integration" (Osouli et al., 2008). This model provided by the Software Engineering Institute.

Project management process groups (or process groups) are grouped as follows:

Introductory group processes. Processes carried out in order to define a new project or a new phase of an existing project with permission to start the project or phase.

Planning process group: Processes required establishing the scope of the project, refining the goals, and defining the necessary measures to achieve objectives of the project.

Implementation process group: Processes performed in order to complete the work defined in the project management plan to ensure the project specifications.

Monitoring and control process group. Processes needed for tracking, monitoring, and regulation of development and performance of the project. They identify the areas where changes are needed in the program and initiate the relevant changes.

End process group. Processes performed to finalize all activities of all process groups to end the project or phase formally (Fig. 1).

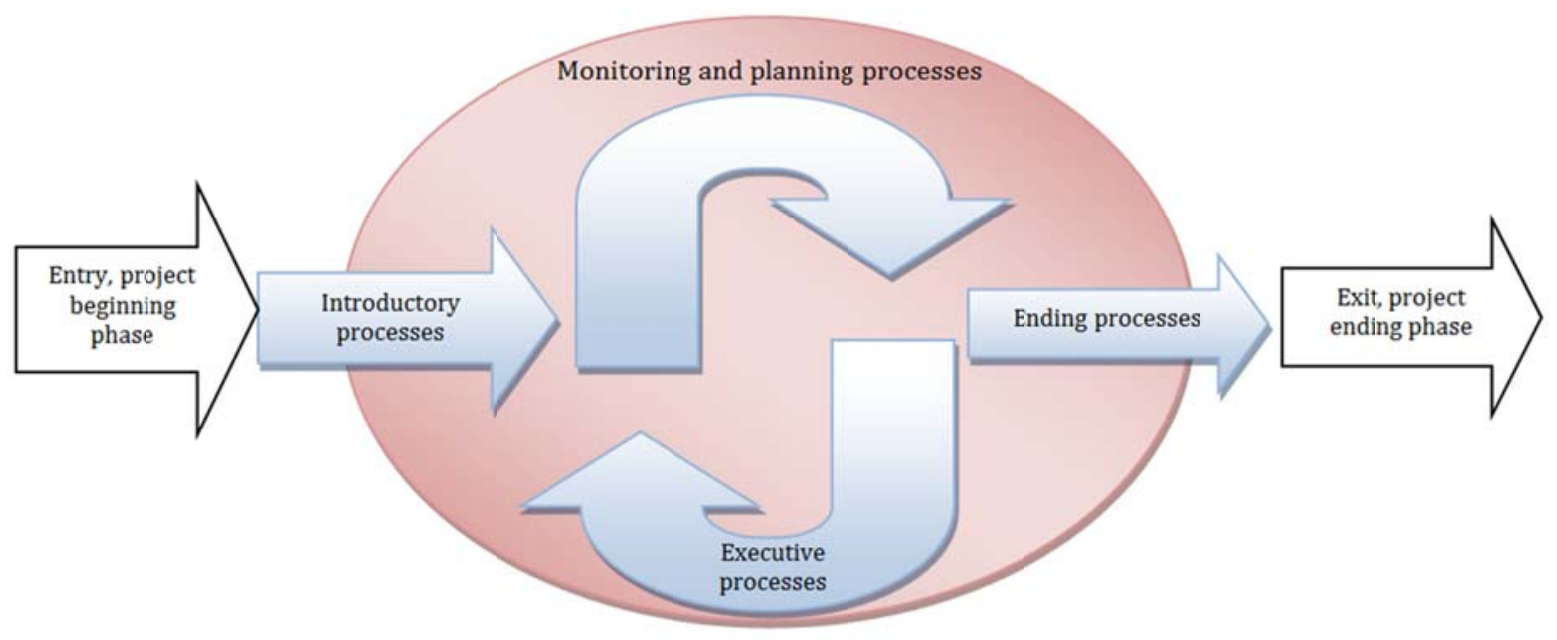

Fig. 1: Project management process groups

\section{Evaluation system of project management performance based on PMBOK standard}

Performance evaluation acts as a closed-loop control system which implements the strategy and policies of the organization and evaluates the function of different levels of the organization and gives feedback. Hence, evaluation process is an information and measurement system at the heart of performance management (Shafae'i and Sarmadi, 2008) process which has a vital role in effectiveness and efficiency of the performance management 
system. It also has a duty to determine the degree of project adaptation and success in achieving the project's objectives. Performance refers both to the action and the result of that action. In other words, performance is defined as today's action which is the prelude to produce a certain amount of the person's output value. After evaluating performance and determining compliance or non-compliance with the PMBOK standard, continuous improvement to achieve the optimal expected limit, i.e., creating Organizational Project Management Maturity Model (OPM3), continues.

Neely expressed the seven main reasons of desire to measure performance in an article (1999):

- Changing nature of work

- Increased competition

- Innovative activities for improvement

- National and international quality awards

- Change of organizational maps

- Changes in foreign demands

- Impact of Information Technology

It should be noted that change in criteria effect the organizational behavior such that the organization adopts those criteria for improvement and gaining higher scores and takes steps for implementation on this basis. Questions that will be raised before establishment of a performance evaluation system are as follows: What should be measured? If the focus is on the performance in the project environment, what is to be measured is performance. But is what we measure performance process or performance outcome? Do we want to know the sectional proof of performance and whether managers can work on a certain standard over a period of time? Do we want to do that measurement individually or as a group? Do we merely measure what managers and supervisors do or we also consider how well it is done?

Several questions raised in the evaluation and assessment also show the subsequent key features. In a system of measurement that is consistent with a standard, focus on performance results and evaluation of managers is during a regular period. The important point is whether the performance evaluation assesses competency (Bayati, 2006) or excellence. What is essential in performance evaluation is the level of compliance with the standard of project management knowledge and this compliance should be evaluated in comparison with all management processes. The goal of any performance measurement system (Bolourian et al., 2007) is to determine the success or the level of harmony between the components for achieving objective of the performance measurement system. Accordingly, the performance measurement frameworks provided by the researchers are divided into two types of structural and procedural measurement frameworks. The difference between structural and procedural frameworks is related to system definition. Procedural measurement frameworks try to design a step by step procedure to create and implement a measuring system and pay more attention to the system's third dimension (relationship between components); and because of lacking the structural dimension (components), they do not allow for the selection and management of unique performance criteria. Similarly, the structural frameworks regard the second dimension of performance measurement system and provide a specific guidance for defining criteria based on measurement dimensions.

The performance measurement (Teymouri and Ali, 2009) system includes a number of performance criteria.

By identifying the key criteria and indicators in PMBOK processes in the project population as well as interviewing and distributing questionnaires, the level of project management maturity is measured. First, the project manager, managers, and supervisors are encouraged to complete the questionnaires by self-declaration. After collecting the questionnaires, the items contained in them are audited using detailed interview. Due to the unique characteristics of each project, evaluation is performed to assess the standard application level of project management in the general framework of evaluation process in areas of standard PMBOK. This is done using a general assessment and selfassessment questionnaire based on Dennis Bowles model as well as detailed evaluation tool of project management.

\section{Developing evaluation indices}

The first and most important step in designing the performance evaluation system is to identify and develop the practical measures commensurate with the responsibilities of the project manager and project team managers regarding their position in accordance with the process groups in the project. These indexes must be based on PMBOK standard to be measurable. This means that the indicators should be measurable. For measurement, the indexes should certainly be quantitative. Measures and criteria are defined based on the following indices:

- Key indicators: set of parameters measuring a specified criterion for a component.

- Key criteria: conditions, predefined values and measures determined in the scoring model for assessing alignment with the objectives.

- Key performance indicators: a measure which provides the possibility of assessment and reporting. Audit is a systematic, independent and documented process for obtaining evidence and its factual evaluation for meeting the criteria.

The criteria were extracted and classified commensurate with the duties of directors and highranking officials in the project management team by getting comments of each and regarding the requirements of PMK areas in accordance with the PMBOK standard. The important point is that all the criteria must be instances of the areas of knowledge management so that we can audit them after 
quantification based on performance evaluation process.

Examples of performance evaluation indicators based on objective, measures, and output in accordance with the standard PMBOK
According to the following table, the expected outputs are defined and categorized for each area of the project management knowledge based on standards (Table 1).

Table 1: Categorize project management knowledge area

\begin{tabular}{|c|c|c|c|}
\hline Area & Goal & $\begin{array}{c}\text { Metric measurement } \\
\text { target }\end{array}$ & Main outcomes expected \\
\hline $\begin{array}{c}\text { Integrity } \\
\text { management }\end{array}$ & $\begin{array}{l}\text { Identify, define, combine and } \\
\text { coordinate project management } \\
\text { processes }\end{array}$ & $\begin{array}{l}\text { Contrary to other } \\
\text { metrics }\end{array}$ & $\begin{array}{l}\text { Project charter, project } \\
\text { plan }\end{array}$ \\
\hline Scope Management & $\begin{array}{l}\text { The project must consist of the works } \\
\text { required for the project }\end{array}$ & $\begin{array}{l}\text { The ratio of scope } \\
\text { changes }\end{array}$ & $\begin{array}{l}\text { Detailed statement of } \\
\text { scope }\end{array}$ \\
\hline Time management & Timely completion of project & Time performance & Project Scheduling \\
\hline Cost Management & $\begin{array}{c}\text { Completion of the project with } \\
\text { approved cost }\end{array}$ & Cost performance & Cost planning \\
\hline $\begin{array}{c}\text { Quality } \\
\text { management }\end{array}$ & $\begin{array}{l}\text { Fulfill the committed qualitative } \\
\text { requirements }\end{array}$ & $\begin{array}{l}\text { Duplication ratios, } \\
\text { customer satisfaction }\end{array}$ & $\begin{array}{c}\text { Quality design, reports on } \\
\text { control and quality } \\
\text { assurance }\end{array}$ \\
\hline $\begin{array}{l}\text { Human Resource } \\
\text { Management }\end{array}$ & $\begin{array}{c}\text { Supply and logistics, maintenance, } \\
\text { human resources required for the } \\
\text { project }\end{array}$ & $\begin{array}{c}\text { Satisfaction of } \\
\text { authorities of } \\
\text { responsibility centers, } \\
\text { Productivity and job } \\
\text { satisfaction of staff }\end{array}$ & $\begin{array}{c}\text { Project structure, project } \\
\text { team }\end{array}$ \\
\hline $\begin{array}{l}\text { Communications } \\
\text { Management }\end{array}$ & $\begin{array}{l}\text { Production, collection, distribution, } \\
\text { maintenance of project information }\end{array}$ & $\begin{array}{l}\text { Accuracy and } \\
\text { timeliness of data of } \\
\text { each beneficiary for } \\
\text { his share }\end{array}$ & $\begin{array}{c}\text { Communications program, } \\
\text { Performance reporting, } \\
\text { Expectations of } \\
\text { stakeholders }\end{array}$ \\
\hline Risk management & $\begin{array}{l}\text { Planning, identifying, analyzing, and } \\
\text { responding to project risks }\end{array}$ & $\begin{array}{c}\text { Ratio of unmanaged } \\
\text { risks }\end{array}$ & Risk program \\
\hline $\begin{array}{l}\text { Procurement } \\
\text { management }\end{array}$ & $\begin{array}{l}\text { Providing products and services of } \\
\text { projects outside it }\end{array}$ & $\begin{array}{l}\text { Suppliers satisfaction, } \\
\text { customer satisfaction } \\
\text { (in this case, the } \\
\text { project } \\
\text { implementation team) }\end{array}$ & $\begin{array}{l}\text { Procurement applications, } \\
\text { purchase contracts }\end{array}$ \\
\hline
\end{tabular}

The results were analyzed after audit of the authorities in accordance with descriptions of duties within the project organization framework and in field of the related knowledge using self-declaration and interview methods, .It is obvious that a method should be used for scoring the quantified criteria. To facilitate assessment, some weight and scores were considered for the indexes and then, regarding the weight of each index, AHP (Farahani, 2006) was used to analyze the scores obtained in audit.

\section{The issue of selecting options on the basis of criteria}

In general, decision-making process is divided into two categories regarding decision space: continuous and discrete. Decision making in discrete space is divided into two categories of single criteria. The criteria are also divided into three qualitative, quantitative, and mixed (qualitative and quantitative) categories. Hierarchical AHP is a method that allows correct decision making in the presence of qualitative, quantitative, and mixed criteria.

\section{Performance evaluation and scoring the project management checklist}

After finalizing indexes and weighting each of them by getting the comments of authorities and the project team as well as previous experiences in using AHP for each index, we defined a number for each index from zero to 100 according to Table 2 .

After preparation of the final scoring table in the project management checklist, self-declaration questionnaires were distributed and completed by the project management team. Then, audit was done in the final assessment using interviews (Figs. 2 and 3).

\section{Conclusions}

The final result is obtained from the study and comparison of the audit scores in process groups of 9 knowledge areas of project management in compliance with the standard and based on the following graph.

It is observed that project management performance shows the average condition in comparison with the process groups and knowledge domains based on PMBOK standard. The organization is weak in areas where it has attained scores less than 50 . It should be tried to improve the areas where the score is more than 50 in order to achieve organizational maturity and OPM3 model (Fig. 4). 
In comparing the status of project management knowledge with the expected values, it can be seen after evaluation that the lowest scores are in the areas of risk management and communication management, and the highest scores are in the areas of quality management, time management, and scope management.

Table 2: Project management checklist scoring guide

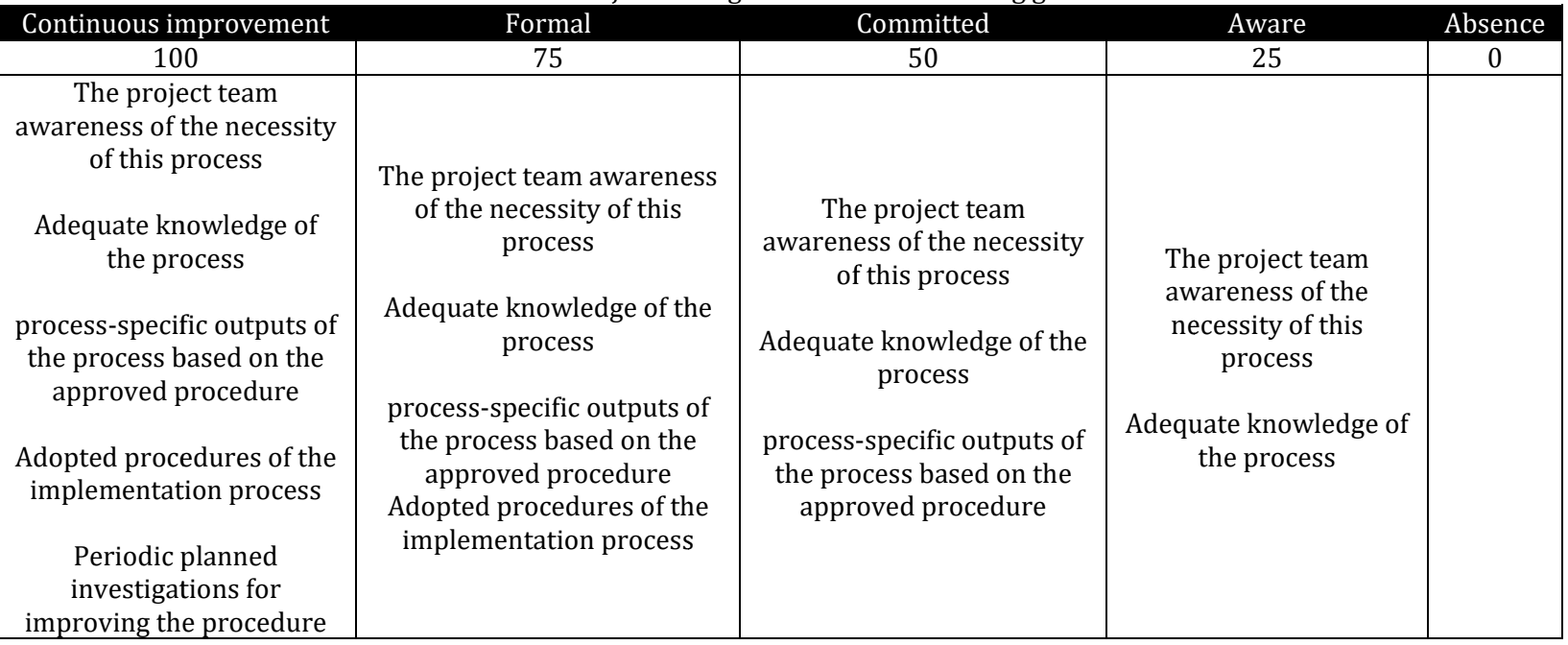

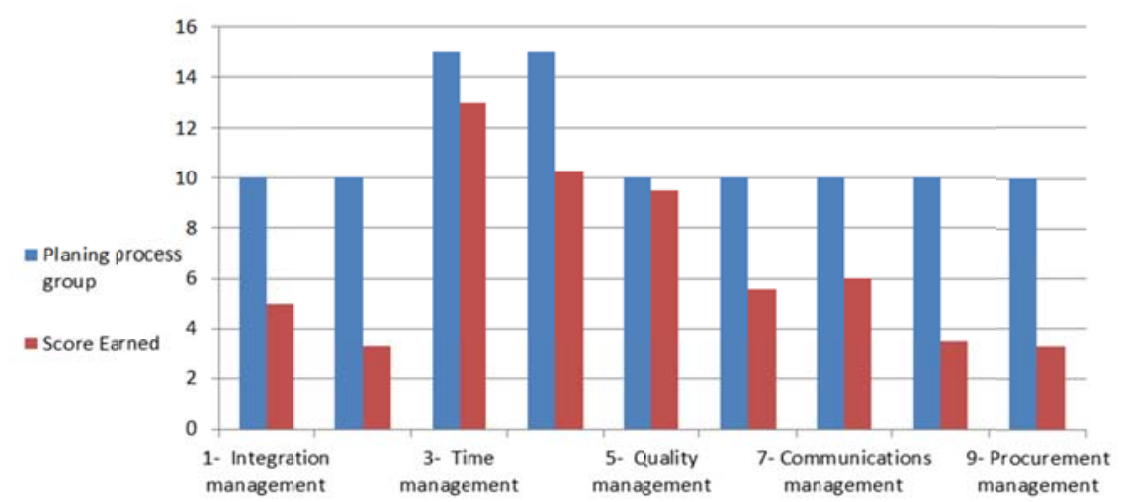

Fig. 2: Comparative graph in the areas of knowledge management in the planning process group based on PMBOK standard

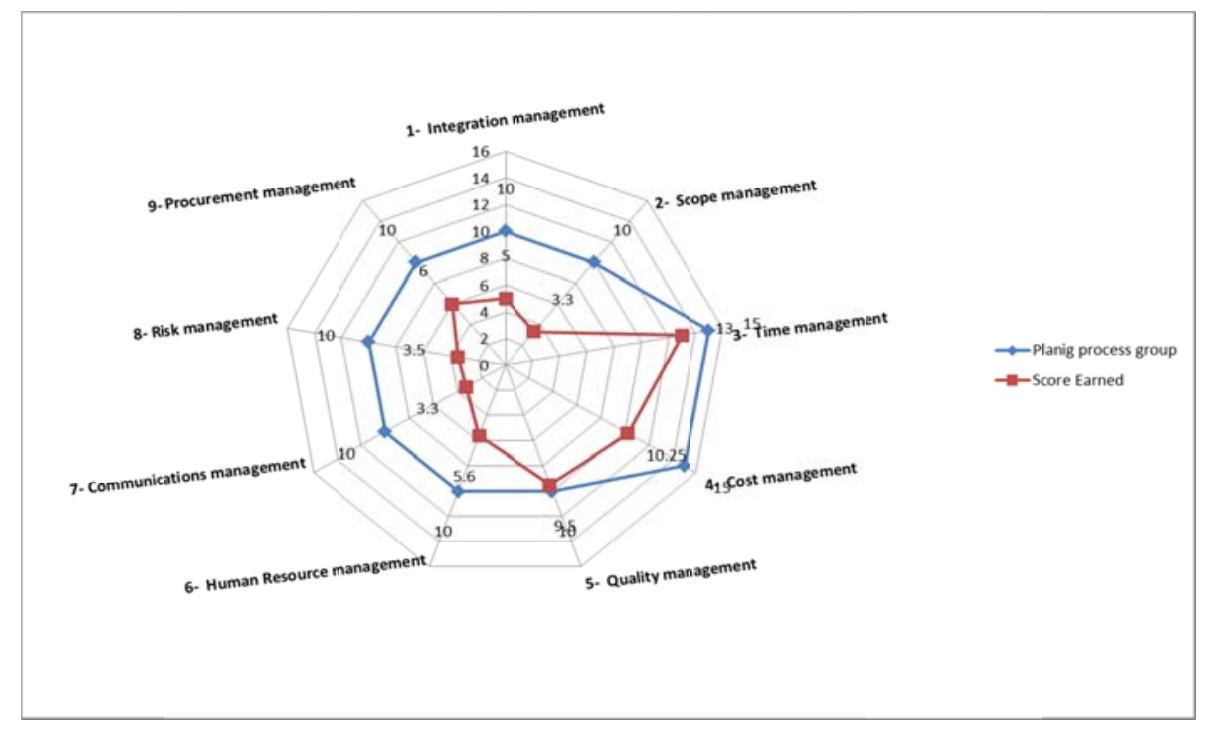

Fig. 3: Comparative radar graph in the areas of knowledge management in the planning process group and score earned

Since the audit was conducted for evaluation, results of the audits were used to determine the extent of the use of such tools in the field of project management. Then, the general output of knowledge areas was used to determine the output of process groups and outputs of each process. Therefore, the 
analysis and recognition of the root causes of problems and weaknesses of each process are defined.

Hence, project management performance can be evaluated by assessing the process groups as the outputs of 9 groups of project management knowledge; and performance of each director in the project can be assessed and scored. By defining the weaknesses in each field of knowledge, the expected outputs can be strengthened and correctly used and also the ultimate goal of performance evaluation, enhanced efficiency, and managers' effectiveness can be achieved.

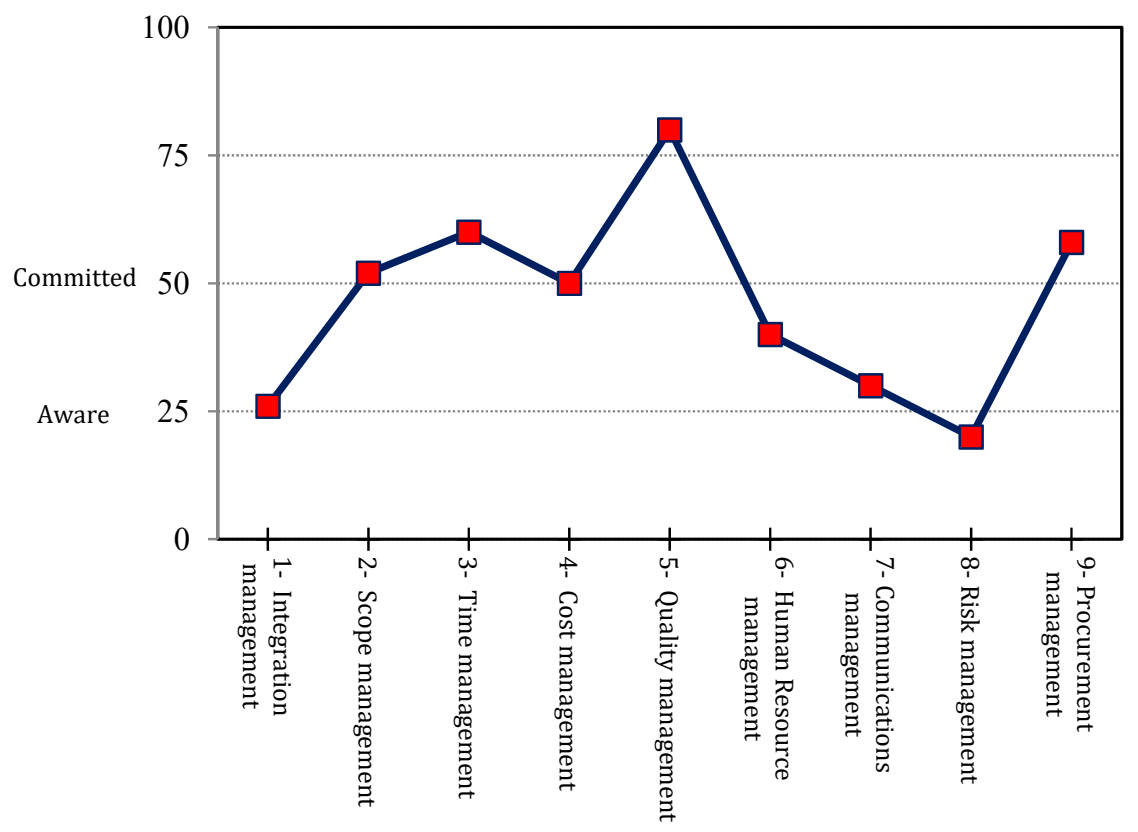

Fig. 4: Project management performance in comparison base on standard

\section{Suggestions and recommendations}

Since the evaluation of the process by which the performance of project managers and formally evaluated at regular intervals and assessed at each stage of the project life cycle to identify and confirm knowledge of strong managers with motivational levers to improve their operational performance. In addition to identifying the weaknesses of managers with accurate planning is necessary to fill.

May be one way process groups is audited and evaluated and even establish a way they are implemented but standard implementation and success of the project simply is not the main goal, but profitability and gain market share experience and lessons learned should be taken into account It is recommended that, at the end of the project reevaluated performance in addition to compatibility with standards referred cases re-examined Finally, the utility and success to be measured.

\section{References}

Bayati A and Naseri H (2006). Project management association: Project manager competency development framework. Rasa Publication, Tehran, Iran: 12- 16.

Bolourian E, Arab $H$ and Makvandi A (2007). Creation of centers of excellence in project management, Bulls, Dennis. $1^{\text {st }}$ Edition, the National Petrochemical Company, Tehran, Iran: 43-56.

Farahani M (2006). Implementing standard PMBOK processes using analytical hierarchy process (AHP). 4 ${ }^{\text {th }}$ International Project Management Conference, Tehran.

Kamandi PK and Darabi H (2009). Project Management Institute (PMI). PMBOK Guide, $1^{\text {st }}$ Edition, Hami Publications, Tehran, Iran: 31-36.

Osouli H, Shakeri A, Samimi M, Mokhtar A Manouchehri $M$ and Naseri H (2008). Comprehensive project management maturity model. $1^{\text {st }}$ Edition, the National Petrochemical Company, Tehran, Iran.

Shafae'i R and Sarmadi P (2008). Performance management in manufacturing industry. $1^{\text {st }}$ Edition, Nasir Publications, Tehran, Iran.

Teymouri L and Ali AMH (2009). Measurement of business performance. $1^{\text {st }}$ Edition, University of Science and Technology, Tehran, Iran.

Zoka'ei AM (2008). Project management institute, PMBOK. $3^{\text {rd }}$ Edition, Adineh Publications, Tehran, Iran: 54-63. 